\title{
El escudo de Atenea: cultura visual \\ y guerra en Colombia*
}

THE SHIELD OF ATHENA: VISUAL CULTURE AND WAR IN COLOMBIA

O ESCUDO DE ATENEA: CULTURA VISUAL E GUERRA NA COLÔMBIA

\section{Rubén Darío Yepes Muñoz ${ }^{* *}$}

Cuadernos de Música, Artes Visuales y Artes Escénicas

/ Volumen 9 - Número 2 / julio - diciembre de 2014

/ ISSN 1794-6670/ Bogotá, D.C., Colombia / pp. 23-43

Fecha de recepción: 15 de mayo de 2014 | Fecha de aceptación: 16

de junio de 2014. Encuentre este artículo en

http://cuadernosmusicayartes.javeriana.edu.co/

doi:10.11144/Javeriana.mavae9-2.eacv

* Este artículo hace parte de la investigación que adelanta el autor en relación con su tesis de doctorado en la Universidad de Rochester, USA.

**Estudiante de doctorado en Estudios Visuales y Culturales en la Universidad de Rochester. Magíster en Estudios Culturales de la Pontificia Universidad Javeriana, Bogotá, Colombia. Licenciado en Artes de la Universidad de Antioquia. 


\section{Resumen}

Este artículo propone un marco conceptual para entender el rol de la cultura visual en relación con la construcción de la memoria histórica del conflicto armado colombiano y la superación de su legado de violencia, sufrimiento y horror. El artículo pregunta por las capacidades del arte, la fotografía y el cine en relación con esta tarea; para ello, recurre a ejemplos específicos tomados de estos campos de producción visual. Se propone que la cultura visual contemporánea en Colombia hace su trabajo en relación con la guerra como mediación, es decir, como producción de una interrelación de elementos dispares. En relación con este trabajo como mediación, se propone también la noción de ecología de las imágenes, con la cual se busca entender los modos en los que las imágenes se relacionan entre sí para producir sentido y afectos. Hacia el final, se esboza la noción de evento visual, con la cual se busca enfatizar el carácter relacional del rol mediador de la cultura visual.

Palabras clave: cultura visual en Colombia; arte y guerra; arte y política; mediación; ecología de imágenes; evento visual

\section{Abstract}

This article proposes a conceptual framework with the purpose of understanding the role of visual culture in the construction of the historical memory of the armed conflict and the transcending of its legacy of violence, suffering and horror. The article reflects on the capacities of art, photography and film in relation to this task; with this purpose, it resorts to specific examples from these fields of visual production. Further, it proposes that contemporary visual culture in Colombia does its work visà-vis the war as mediation, i.e., as the production of a relationality of disparate elements. The article also proposes the notion of the ecology of images in relation to said mediational work, which seeks to understand the ways in which images interrelate to produce sense and affects. Towards the end, the article articulates a working notion of visual event, which seeks to emphasize the relational character of the mediational role of visual culture.

Keywords: Colombian visual culture; war and art in Colombia; art and politics; mediation; ecology of images; visual event

\section{Resumo}

Este artigo propõe uma estrutura conceitual para a compreensão do papel da cultura visual em relação à construção da memória histórica do conflito armado colombiano e a superação seu legado de violência, sofrimento e horror . O artigo faz as capacidades de arte, fotografia e filme em ligação com esta tarefa ; ao fazer assim, ele utiliza exemplos específicos a partir de tais campos de produção visual. Propõe-se que a cultura visual contemporânea na Colômbia faz o seu trabalho em conexão com a guerra como a mediação, ou seja, como a produção de uma inter-relação de elementos díspares. Em conexão com este trabalho como a mediação, propõe-se a noção de ecologia de imagens, que busca entender as formas em que as imagens se inter-relacionam para produzir significado e afetos. Para o efeito, também propôs a noção de evento visual, que busca enfatizar o caráter relacional do papel mediador da cultura visual.

Palavras-chave: cultura visual na Colômbia; da arte e da guerra; arte e política; mediação; ecologia de imagens; evento visual 
Nunca la cuestión del rol social y político de la cultura en Colombia había sido tan perentoria como ahora, en este momento tardío de la historia del país en el que su larga guerra interna parece más anacrónica que nunca -aun cuando las inequidades e injusticias que la han nutrido siguen existiendo. Al momento de escribir este ensayo se llevan a cabo conversaciones de paz entre el gobierno y las FARC, habiendo un moderado optimismo por el desenlace ${ }^{1}$. Sin embargo, cualquiera que sea el resultado, es necesario atender la tarea de construir la memoria histórica del conflicto armado, de permitirle a sus víctimas voz y presencia, de dar cuenta del horror y el trauma producidos por décadas de guerra. El pasado, Nietzsche (2009) enseña, es útil en tanto está imbricado con el futuro en el presente, esto es, en tanto que nos sirve para entender el presente con el fin de movernos hacia los futuros que imaginamos; una sociedad de posconflicto debe observar su pasado si quiere encontrar los futuros que desea. Se trata de un imperativo ético, el cual debe ser atendido -y ha sido atendido- por los artistas y productores culturales².

¿Qué pueden contribuir el arte, la fotografía y el cine de cara a esta tarea imperativa? ¿Cuál ha de ser el rol de estas formas de cultura visual en relación con el legado de violencia y sufrimiento del conflicto armado y de cara a una posible sociedad de posconflicto? En este ensayo me refiero al arte contemporáneo, la fotografía y el cine sin implicar que estas formas de cultura visual pueden hacer una mayor contribución que otras formas. De ninguna manera pretendo retornar a las viejas distinciones entre arte "culto" y arte "popular", entre lo "alto" y lo "bajo", o entre formas culturales de "mayor" y de "menor" importancia. El trabajo de otras formas de la cultura visual de cara a la guerra colombiana -uno piensa particularmente en la televisión, el grafiti y la caricatura política- merece ser estudiado tanto como el tipo de producción cultural a la que me refiero aquí, pero se encuentra más allá del alcance de este ensayo y de mi trabajo académico.

Mi propósito no es analizar las capacidades específicas del arte, la fotografía y el cine en relación con las preguntas que guían este ensayo, más bien se trata de construir un marco conceptual a partir del cual el trabajo de estas formas de cultura visual en relación con la guerra en Colombia puede ser entendido de un modo general. Recurriré a ejemplos de estas formas de cultura visual con la salvedad de que, en cada caso, dichos ejemplos no deben ser vistos como manifestación de un privilegio otorgado al medio específico mencionado en relación con los conceptos o temas considerados en cada sección. Consideraré cada ejemplo en términos de sus elementos estéticos específicos, pero el propósito principal es relacionarlos con el marco conceptual de carácter más amplio que propongo aquí. En tanto que son ejemplos, los trabajos que considero pueden ser intercambiados con otros que buscan realizar un trabajo similar en relación con el conflicto armado.

La tarea de recordar el pasado y de atender los legados del conflicto pesa formidablemente sobre los hombros de la sociedad colombiana en su totalidad. Claro está, los historiadores, los sicólogos y los trabajadores sociales están llamados a asumir esta tarea, pero la producción cultural -visual y no visual- también puede contribuir, empero en su propia manera, a través de sus propios medios. El arte, la cultura, pueden atraer nuestra atención en relación con eventos y procesos sociales frente a los cuales el poder dice "no mire, siga"; pueden producir significado allí donde el discurso oficial se mantiene en silencio ${ }^{3}$. Crucialmente, pueden jugar un papel importante en la producción de la motivación necesaria para llevar a cabo las tareas mencionadas. Pero el trabajo que realiza la cultura visual para hacer que el pasado sea visible y sensible, la labor que hace con el fin de producir sentido y motivarnos a asumir la tarea de 
construir memoria se entiende inadecuadamente en términos de "representación" -si hemos de entender por este término la producción de semblanza o parecido ${ }^{4}$ Más bien, la cultura visual contemporánea hace su trabajo en relación con la guerra como mediación, es decir como producción de una interrelación de elementos dispares.

Para dar un ejemplo de sobra conocido: la instalación Noviembre 6 y 7 de Doris Salcedo se ha convertido, desde que sus 280 sillas descendieron lentamente por la fachada del Palacio de Justicia en Bogotá en 2002, en un símbolo de la trágica toma del edificio sede de la Corte Suprema de Justicia (figura 1). La instalación no representó los eventos que comenzaron con la captura del edificio por parte de un comando del M-19 y terminaron con la azarosa retoma por parte del ejército. En ninguna parte se puede encontrar una semblanza o una narrativa del evento al cual se refiere la instalación. Más bien, lo crucial es su agencia en tanto mediación, la interrelación de diversos elementos: Noviembre 6 y 7 interrelacionó el carácter metonímico de las sillas, la duración de la acción, el valor simbólico del edificio del Palacio de Justicia y la trágica historia de los eventos que sucedieron allí. Es a través de este ensamblaje de elementos dispares que la instalación media la guerra. Aún al momento de escribir este ensayo, años después de su ocurrencia y mediada a su vez por los libros de historia del arte y otras publicaciones, la instalación continúa recordándonos que todavía hay temas que deben ser resueltos en relación con este nefasto evento.
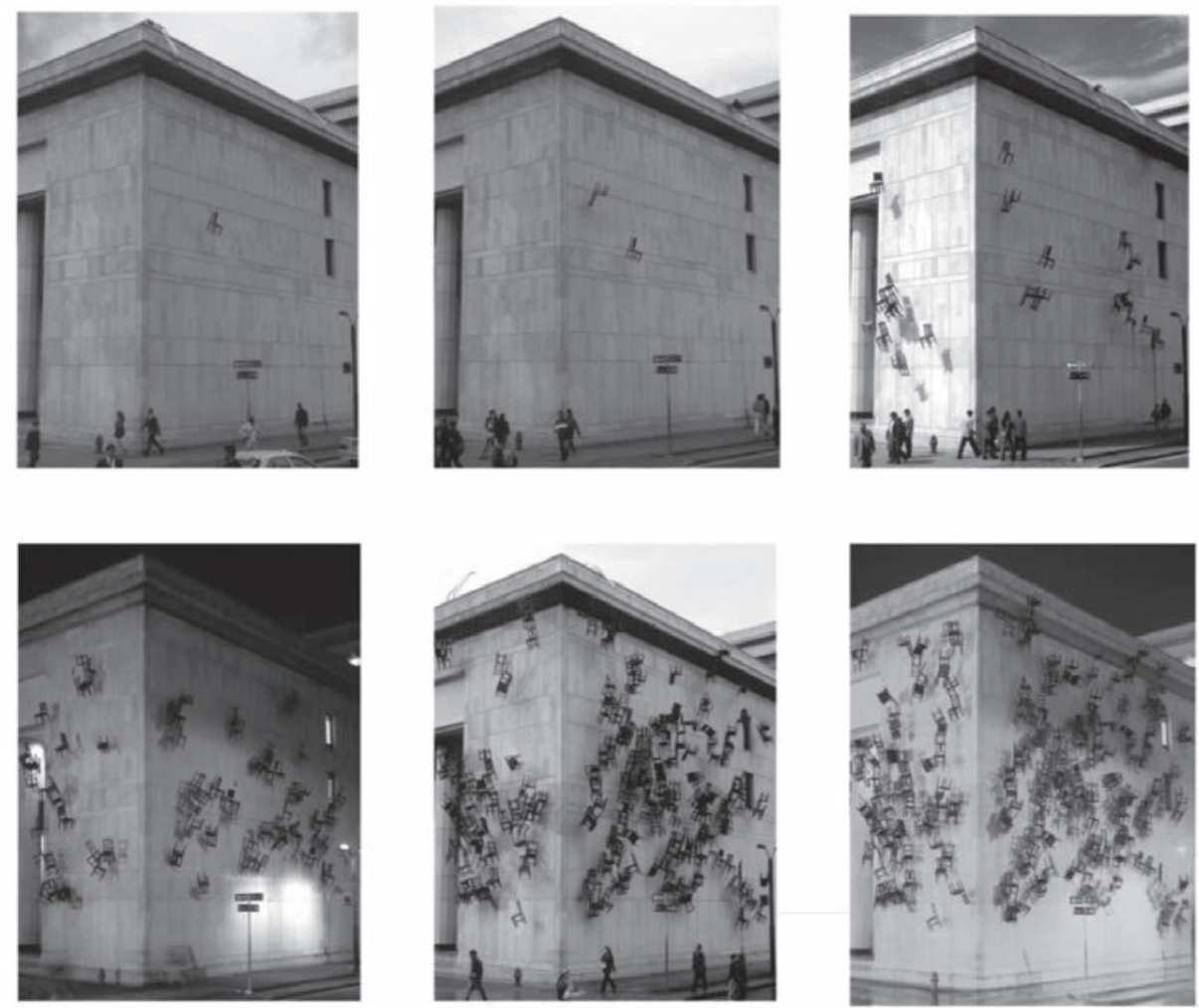

Figura 1. Doris Salcedo, Noviembre 6 y 7, 2002. Imagen cortesía de la galería Alexander and Bonin.

¿Por qué enfocarse en la cultura visual? Claramente distintas formas de producción cultural pueden hacer -y efectivamente han hecho- un trabajo relevante en relación con la guerra. En este sentido, no sostendría que hay una diferencia substancial entre la cultura "visual" y otras formas de producción cultural, ya sea textual o auditiva ${ }^{5}$. En cierta medida, todas las formas de 
producción cultural son visuales: incluso en las formas que no se apoyan directamente en la imagen, la imaginación, sin embargo, juega un papel importante en relación con su producción de sentido y afecto. E inversamente, todas las formas de cultura visual contienen elementos discursivos en mayor o menor medida. La diferencia entre distintas formas culturales en relación con lo visual no es substantiva, sino, como dice W. J. T. Mitchell (2013), una diferencia de grados: hay formas culturales que se apoyan en mayor grado en lo visual, mientras que hay otras que se apoyan en lo textual o lo auditivo. En el contexto de la guerra colombiana, las dimensiones textuales y discursivas de la cultura visual frecuentemente juegan un importante papel como marco de aquello que las imágenes presentan, como reguladores de la apertura inherente a las imágenes.

Quiero argüir que, aparte de la diferencia en grados de visualidad que menciono arriba, hay otra diferencia importante entre la cultura visual y otras formas culturales, la cual es consecuente con el carácter abierto de las imágenes y del arte. Me tomo en serio la respuesta que Mitchell da a su pregunta retórica "¿Qué quieren las imágenes?" (1996). Las imágenes -y, podemos añadir, la cultura visual en general- tan solo quieren ser interrogadas en relación con su deseo (Mitchell, 1996, p.81). Ellas no son portadoras mercúreas de un mensaje, sino que son signos flotantes que provocan preguntas que no están determinadas a priori, ya que en ninguna parte las imágenes anuncian lo que quieren hasta que son interrogadas. Su deseo es relacional. Pero la diferencia a la que me refiero también tiene que ver con otra dimensión de la cultura visual que Mitchell no considera en su conocido ensayo sobre el deseo de las imágenes, a saber, su producción de afectos. El trabajo de la cultura visual contemporánea en relación con el conflicto armado se entiende de manera insuficiente si no se toma en cuenta su producción afectiva; de hecho, su producción de afectos es frecuentemente un factor fundamental, el elemento central de la agencia de la cultura visual en relación con la guerra.

La diferencia entre la cultura visual y otras formas de producción cultural a las que me refiero se puede enunciar así: mientras que todo artefacto cultural produce sentido y afecto en relación con otros artefactos culturales, la cultura visual tiende a darle prevalencia a su relación con otras imágenes, de cara al propósito de construir sentido. De nuevo, no se trata de una distinción absoluta, sino de una cuestión de grados de diferencia. Sin embargo, la diferencia es suficiente como para justificar la consideración por separado de aquellas formas de producción artística que le dan prioridad a lo visual. La cultura visual contemporánea en Colombia hace su trabajo en medio de una esfera de imágenes más amplia que construye representaciones hegemónicas del conflicto armado, es decir, la cultura visual se relaciona con la guerra en medio de una ecología de las imágenes. En ambos casos -cultura visual contemporánea, la esfera de imágenes que produce representaciones de la guerra- hay un trabajo de mediación, pero la agencia de las primeras emerge en contraste con la agencia de las últimas.

\section{MEDIACIÓN}

La tarea de la cultura visual en relación con el conflicto armado no es representar a este último, sino servirle de mediación. ¿Qué significa "mediar" el conflicto con su legado de violencia y horror? ¿A quién interpelan las mediaciones de la cultura visual contemporánea? Dentro de un modelo comunicativo, mediación denota un proceso activo, esto es, la agencia del objeto o la acción mediadora. El concepto de mediación funciona, en un sentido 
general, como la posibilidad de una puesta en relación de términos dispares, actualizando así un contenido particular ${ }^{6}$. El posible salvamento de una distancia es su rasgo distintivo. Si se trata de una posibilidad, y no necesariamente de un logro, es porque el contenido es el resultado de una relación, no un mensaje transmitido por el objeto mediador, aun cuando sea retrospectivamente asignado a este último. Así, tomo de este modelo comunicativo la agencia del objeto mediador, pero, de manera más importante, tomo el carácter relacional de la mediación, su capacidad de construir puentes entre distancias a través de la constitución de una interrelación. Mientras que es posible hablar de un objeto mediador, el proceso de la mediación es algo que ocurre a través del ensamblaje de términos dispares.

Mediar el conflicto significa salvar la distancia entre el espectador y una serie de objetos, sujetos y eventos dispares relacionados con el conflicto. Pero poco se logra intentando representar la guerra, con su producción de sufrimiento, violencia y trauma social. Lo anterior ocurre porque estos elementos no son contenidos, sino que son afectos, fuerzas ejercidas sobre el cuerpo y pasiones que el cuerpo individual o colectivo ponen en acto. Si se toman como contenidos, solo pueden ser transmitidos a través de signos -lo cual solo logra disminuir su fuerza. Aquí debemos trascender las definiciones de la mediación establecidas dentro de la teoría de la comunicación, en donde el concepto suele encontrarse inscrito en un marco semiótico. El uso de mediación para referirse también a la producción de afectos solicita que el concepto no sea definido exclusivamente a través de su relación con la producción de significado o sentido. Mediar el afecto significa conducirlo, promoverlo, producir fuerzas que actúan sobre el espectador con intensidad y calidad análoga a las de las fuerzas inscritas en el objeto mediado.

¿Para quién (potencialmente) se salvan distancias? No, claro está, para los individuos y las poblaciones que viven en medio del conflicto: ellas lo experimentan de manera directa y por lo tanto no necesitan de mediaciones para estar conscientes de su producción de violencia y sufrimiento -lo cual no equivale a decir que no se requieran allí otras formas de mediación. Como sabemos, la guerra colombiana actualmente ocurre predominantemente -aunque no exclusivamente- en zonas rurales apartadas de las grandes ciudades. Como mediación del conflicto, la cultura visual constituye la posibilidad de relacionar la historia de la guerra, sus eventos, sus víctimas y su producción de sufrimiento con los habitantes de las urbes que visitan los museos, las galerías, los teatros y otros espacios culturales en los cuales dicha producción cultural es habitualmente presentada. Hay una dimensión sociológica de los procesos de mediación que no debe ser ignorada (aunque frecuentemente lo es).

Consideremos, por ejemplo, el proyecto La guerra que no hemos visto: un proyecto de memoria histórica del artista Juan Manuel Echavarría, el cual fue presentado por primera vez en el Museo de Arte Moderno de Bogotá (MAMBO) en 2009 (figura 2). Este proyecto constituye un caso interesante de mediación de la experiencia de excombatientes que participaron en las distintas facciones en guerra. Una serie de pinturas realizadas por un grupo de excombatientes plasman, en el estilo ingenuo, casi infantil, de quien no ha recibido formación artística horribles eventos de crueldad, sufrimiento y devastación. A través de este proyecto, las historias y experiencias de los excombatientes se hicieron públicas. Poniendo a un lado el posible potencial terapéutico del proyecto -no debemos olvidar que muchos de los combatientes y excombatientes de la guerra colombiana fueron reclutados siendo niños y son, por lo tanto, víctimas tanto como pueden ser victimarios-, lo importante es que se resaltan las experiencias de personas que han sido en gran medida invisibilizadas por el discurso gubernamental. 


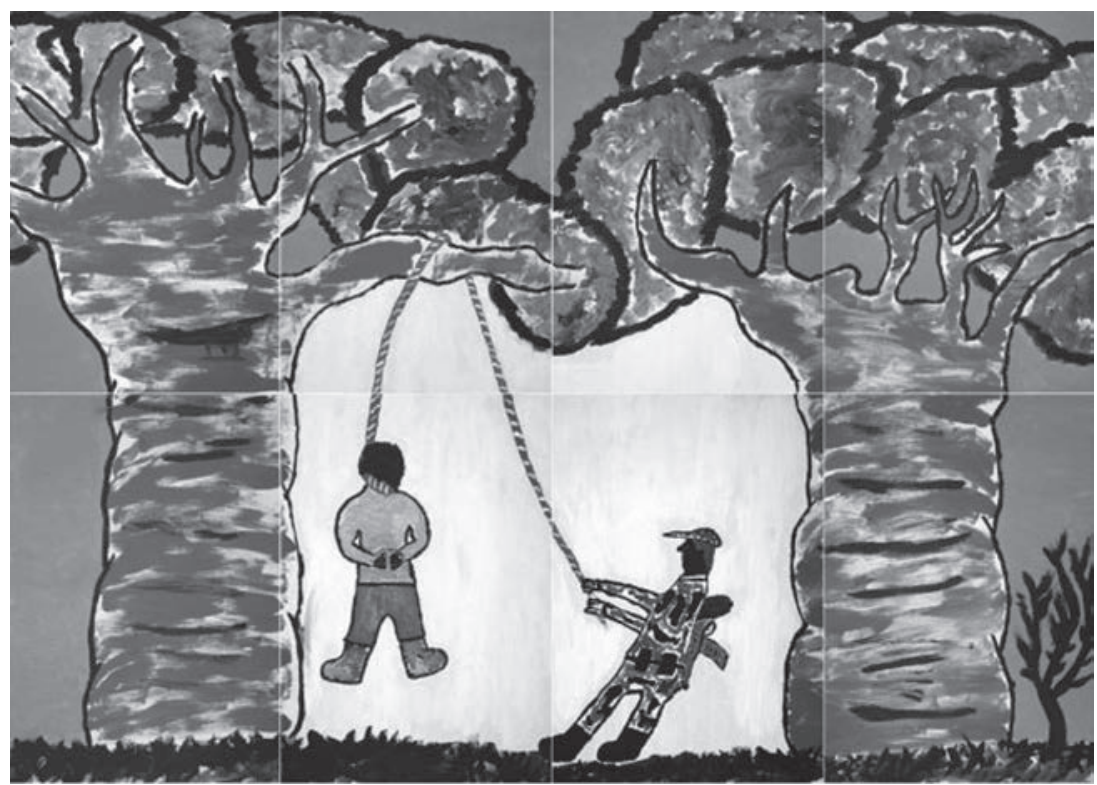

Figura 2. Una de las pinturas de "La guerra que no hemos visto", 2007 Imagen cortesía de Juan Manuel Echavarría.

El énfasis del Estado sobre las experiencias de las víctimas y la retórica redentora que clasifica a los combatientes como "héroes" o "criminales" y "terroristas" ha venido de la mano con la falta de interés en las experiencias de los excombatientes. Así, al otorgarle visibilidad a historias y experiencias que han sido ignoradas en gran medida, el proyecto de Echavarría abre espacios en los cuales los espectadores pueden ver el conflicto a través de un lente diferente, atisbando la complejidad de sus dimensiones y añadiendo así otra capa de densidad a la tarea de construir sentido.

La sociedad colombiana está marcada por los traumas producidos por la prolongada guerra. Esta no solo ha generado una gran cantidad de personas traumatizadas, como varios autores han sugerido, también ha producido una sociedad traumatizada. La larga y prolongada guerra ha creado subjetividades y formas de relación social dañinas. La incapacidad de la sociedad colombiana de afrontar el horror y el sufrimiento producto de la guerra ha alimentado una polarización política radical, una intolerancia e indiferencia crónicas, la normalización de la violencia y la poca valoración de la vida humana ${ }^{7}$. Los síntomas del trauma colectivo deben ser atendidos a través de distintos medios, dentro de los cuales se incluye la mediación de las distancias entre sectores sociales y la sutura del tejido social. Hay sectores de la sociedad colombiana que se pueden beneficiar de las mediaciones culturales en tanto estas últimas son capaces de relacionar a sus audiencias con los traumas y horrores de la guerra, con lo cual se beneficia la sociedad en su totalidad.

El horror es, como dice Julia Kristeva (2006), el derrumbe del orden simbólico, la ausencia de sentido, la sensación de estar frente a un sufrimiento impensable. Pero, para vencer el horror y sus consecuencias traumáticas, es necesario hacer que sus orígenes sean inteligibles. Aquí es donde el carácter relacional del trabajo cultural puede ser de ayuda. Su tarea es evidenciar la naturalización de las actitudes y los comportamientos que mantienen distanciados a aquellos sectores sociales que ven la guerra como un asunto que no les atañe; es desvelar el horror, desenmascarar para esos sectores sociales los eventos horribles que se encuentran en la raíz del trauma colectivo; es poner en relación con dichos sectores sociales las experiencias 
de las víctimas del conflicto. Aquí el problema para la cultura visual en tanto mediación es, como diría Jacques Rancière (2009), encontrar la distancia adecuada: demasiada exposición al horror conlleva el riesgo de producir un estado de desafección y apatía; demasiada poca exposición puede fallar en producir relacionalidades productivas.

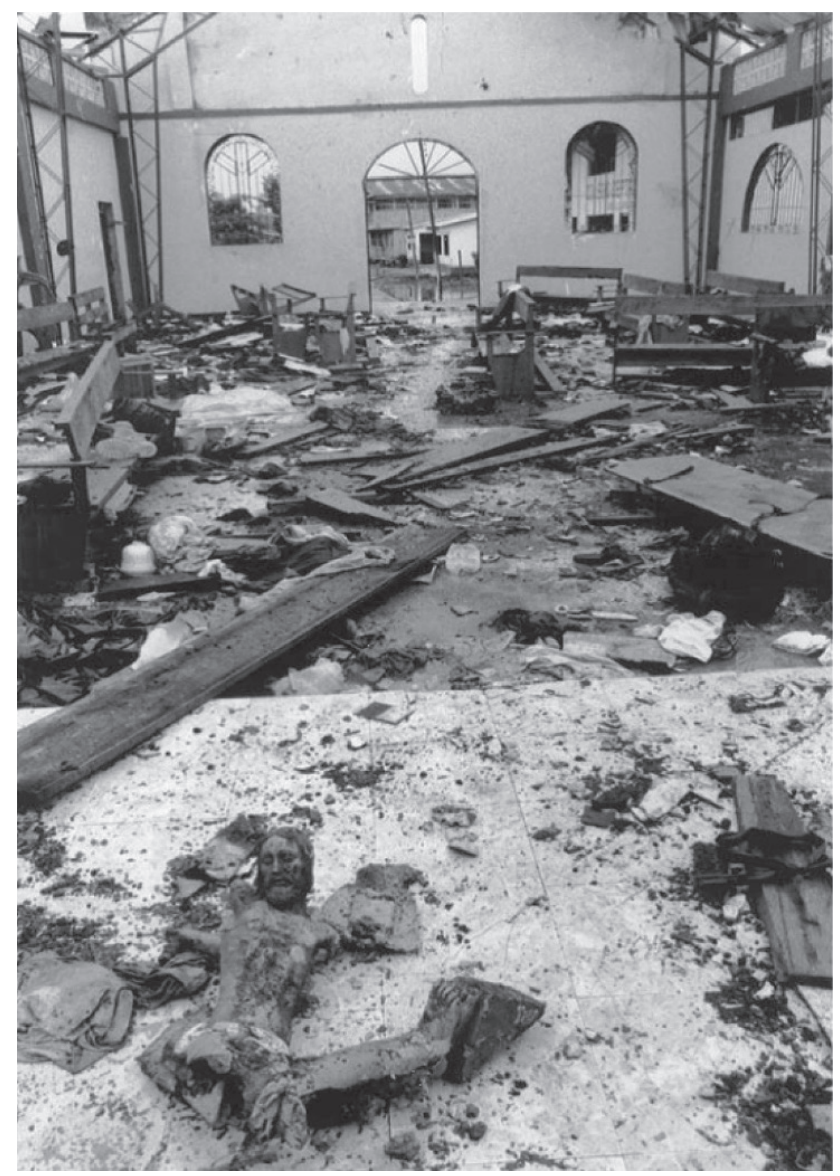

Figura 3. Jesús Abad Colorado, La iglesia en Bojayá después de ser bombardeada por las FARC-EP, 2002. Fuente: Grupo de Memoria Histórica, 2013.

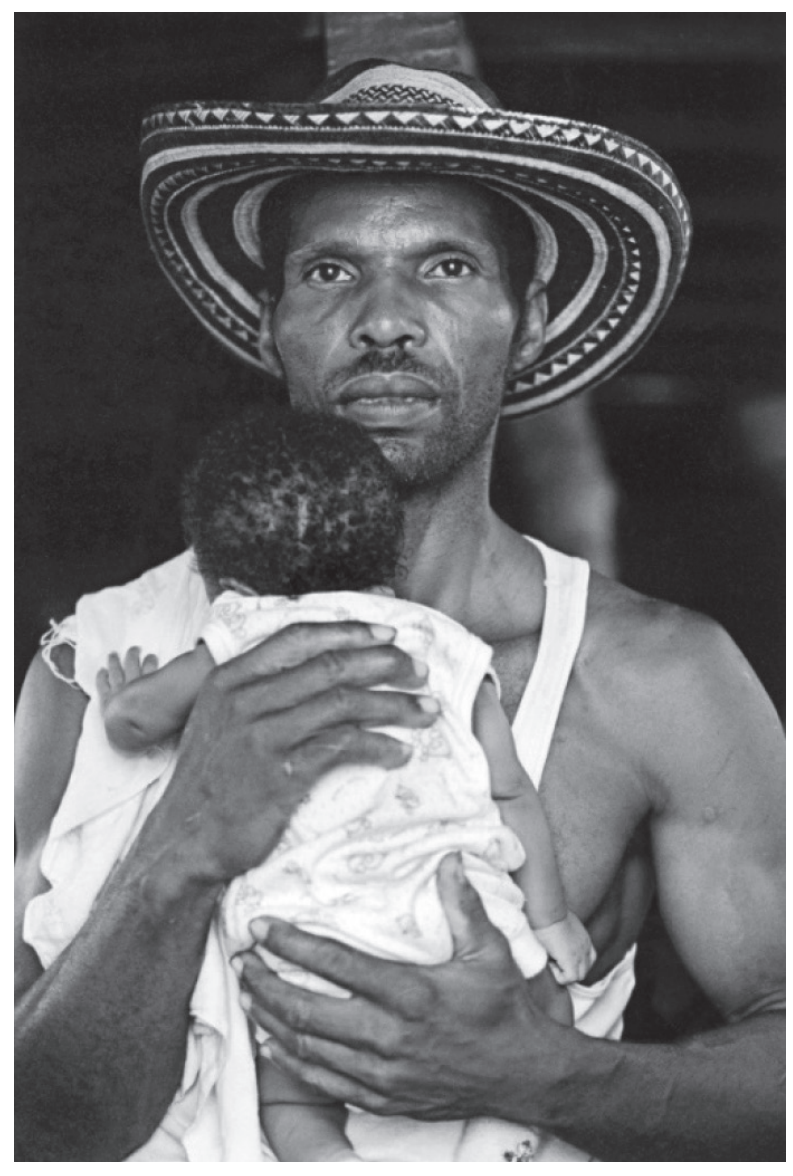

Jesús Abad Colorado, Desplazamiento en Bojayá, 2002. Fuente: Grupo de Memoria Histórica, 2013.

Las fotografías de Jesús Abad Colorado son aquí un ejemplo interesante (figura 3). Colorado es un fotorreportero que se ha dedicado durante más de veinte años a documentar la guerra. Su trabajo ha ganado notoriedad en diferentes contextos, incluyendo circuitos y espacios artísticos. Lo que distingue las fotografías de Colorado de las de otros fotorreporteros es, sobre todo, su distanciamiento. Colorado conscientemente evita la representación "directa" de sufrimiento y violencia extrema; el tono blanco y negro que caracteriza la mayoría de su trabajo actúa como un filtro entre el espectador y los eventos que sus fotografías muestran. De manera más significativa, el fotógrafo evita producir imágenes crudas de violencia y sufrimiento. Muestra respeto por las víctimas de la guerra y, en algunas de sus fotografías más "artísticas", una tendencia hacia la evocación en vez de la descripción gráfica. Estas características se encuentran resumidas en la que es quizás su fotografía más conocida, la cual plasma el interior de las ruinas de la iglesia en Bojayá, donde, en 2002, setenta y cuatro personas buscaron resguardo de la toma del pueblo por parte de las FARC-EP, y murieron cuando el 
grupo guerrillero decidió lanzar cilindros de gas sobre la edificación. Colorado entiende que el trabajo mediador de la imagen fotográfica es más valioso cuando se ubica a la distancia justa, ni demasiado cerca ni demasiado lejos de su referente.

Las fotografías de Colorado señalan hacia la tendencia, ya mencionada, que tienen las imágenes de producir sentido, no solo a través de su capacidad de poner en relación términos dispares, sino también a través de su relación con otras imágenes. Las fotografías de Colorado se distinguen de las formas y estrategias habituales del reporterismo gráfico que ha representado el conflicto en los últimos años; en particular, toman distancia allí donde otros fotógrafos buscan imágenes crudas, representaciones más "directas" de la violencia y el sufrimiento producido por la guerra: filtran el horror de los hechos; documentan sin la ansiedad de mostrar toda la verdad que se puede encontrar en otros lugares. En un sentido general, señalan hacia la imbricación de la cultura visual con una esfera más amplia de imágenes.

\section{LA ECOLOGÍA DE LAS IMÁGENES}

Las imágenes -pinturas, fotografías, artefactos visuales, la imagen en movimiento- se empujan unas a otras; se alimentan unas de otras. Se ensamblan, asocian y colaboran unas con otras, o conversamente luchan y resisten entre sí. Se obstaculizan, disimulando u ocultando a sus semejantes. Ellas pueden emular a otras imágenes, digiriendo y metabolizando sus contornos y apariencia. Inversamente, pueden brindarle a otras imágenes su carne espectral. Los elementos intrínsecos a una imagen pueden enlazar con elementos de otras; conversamente, una imagen puede desorganizar lo que parecía ser cohesivo en otra. Muy pocas cosas son estables en las imágenes, es por esto que su estabilidad tiene que ser producida una y otra vez. En un proceso continuo de interdependencia y competencia, las imágenes modulan su producción de sentido y, por lo tanto, su función mediadora. Al hacerlo, también cambian las formas en que nos afectan: no solo construyen relaciones entre sus respectivos elementos semióticos, sino que también su producción afectiva entra a formar parte de la relación, ensamblándose a su vez con afectos producidos por otras imágenes, al igual que con elementos semióticos y discursivos. El ensamblaje de elementos discursivos y afectivos tanto dentro como entre las imágenes constituye un aspecto insoslayable de su apertura.

La cultura visual labora como mediación dentro de una ecología de las imágenes en la cual sus obras compiten y forcejean o, conversamente, co-laboran. En el contexto de la guerra colombiana, los trabajos de la cultura visual no se relacionan con esta última (si es que lo hacen) como receptáculos independientes, como contenedores autónomos de afectos y de sentido, impasibles a las imágenes producidas en otros contextos. No deben ser vistos como si fueran acertijos, como si fueran formas que presentan contenidos más o menos ocultos. Más bien, ellos toman su sentido y su capacidad de producir afectos, por lo menos en parte, de sus relaciones con la esfera de imágenes que informa, documenta, representa, relata, describe y refleja la guerra.

Sin embargo, la primera tarea de la cultura visual en relación con otras representaciones de la guerra es la de sobresalir, es decir, tomar distancia, distinguirse, emerger como singularidad en medio de la plétora de imágenes de la guerra, buscando así obtener cierta estabilidad en el tiempo. Esta tarea es habitualmente lograda a través del emplazamiento dentro de las estructuras institucionales de la cultura, aunque no es esta la única forma en que se puede realizar. En cualquier caso, es por esto que sigue siendo relevante hablar de arte, aún en el contexto colombiano, aún en esta era poshistórica del arte: los marcos institucionales de la 
cultura alivian a la cultura visual de la dispendiosa tarea de abrir un espacio en medio de la ecología de las imágenes. Debemos aceptar este hecho a pesar de las contradicciones intrínsecas a las instituciones culturales. Una vez que ha sobresalido, la cultura visual que busca mediar el conflicto armado ha tomado el primer paso hacia la instalación de una interrelación propia, la cual le permite colocar otras imágenes a su servicio.
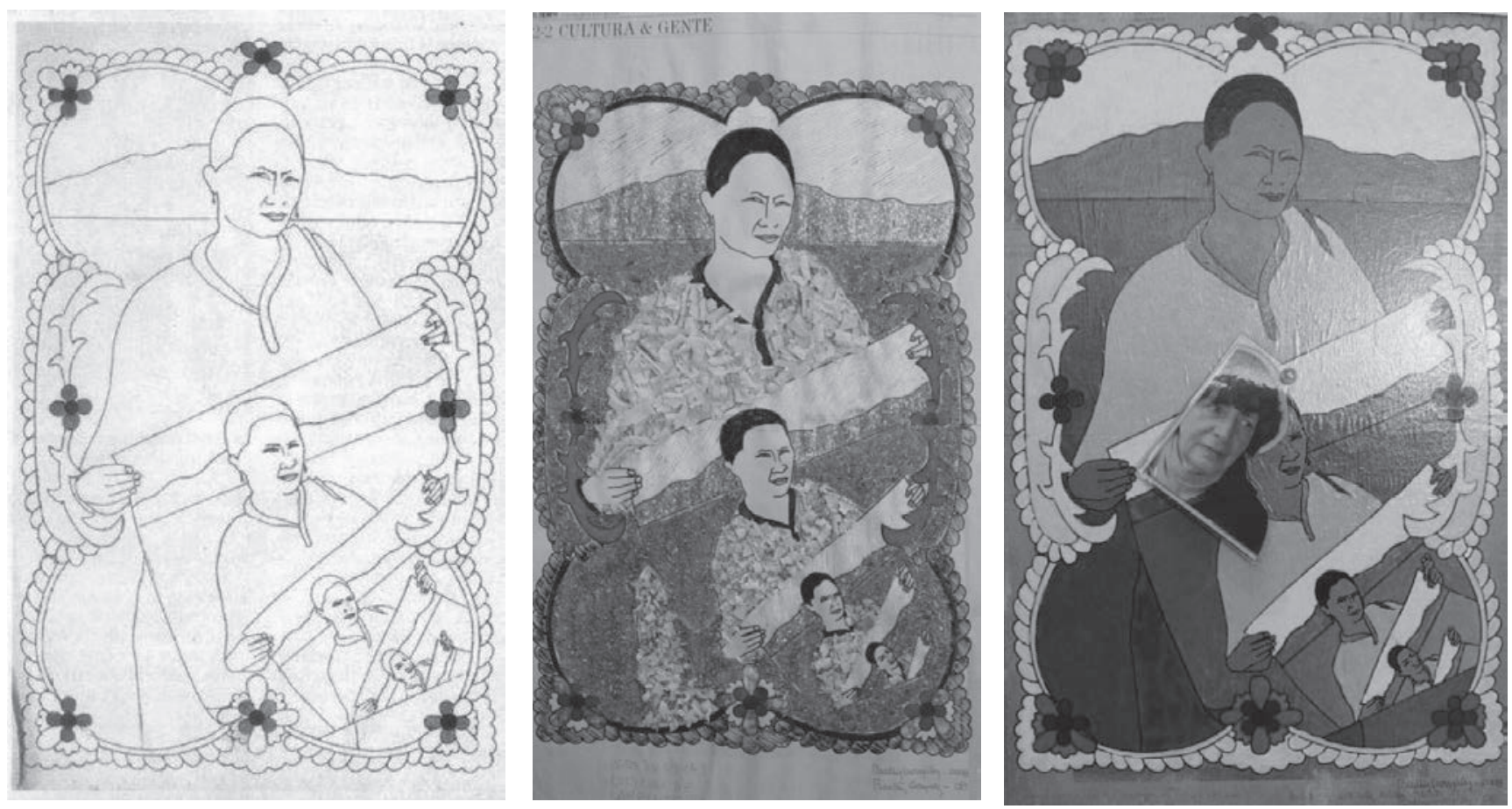

Figura 4. Beatriz González, Ondas de Rancho Grande, 2008. Imágenes cortesía de María Eugenia Niño, Arte Dos Gráfico - Galería Sextante, Bogotá.

Consideremos estas ideas a través de otro ejemplo. Beatriz González realizó una obra conmovedora en 2008, Ondas de Rancho Grande (figura 4). González produjo una imagen dibujada de una fotografía reproducida en un periódico local que retrataba a Yolanda Izquierdo, la líder campesina asesinada por fuerzas paramilitares en 2007 en retaliación por sus intentos de recuperar Rancho Grande, una extensión de tierra expropiada de sus dueños campesinos por los paramilitares, subsecuentemente convertida en hacienda. La imagen creada por González circuló en el mismo periódico que publicó la foto original; la artista invitó a sus lectores a completar la imagen y exhibir los resultados. Con el recuerdo del asesinato de Izquierdo todavía fresco -y efectivamente refrescado por la publicación de la fotografía originaria en la misma edición en la que circuló el dibujo creado por González- la imagen adquirió una presencia que le otorgó a la figura de Izquierdo mayor resonancia pública en relación con lo que había logrado la imagen fotográfica. El dibujo de González funcionó como un catalizador de sentido y afecto en relación con el retrato fotográfico; la fotografía adquirió relevancia a través de la intervención de González. Las imágenes construyen su sentido relacionándose unas con otras, y nos afectan a través de las relaciones que construyen; es relacionándose entre sí que ellas funcionan como mediaciones. La obra de González ilustra esto de manera casi didáctica.

Pero es igualmente importante resaltar que parte de la relevancia que adquirió esta obra deriva del hecho de que fue presentada como una obra de arte, así como del hecho de que González es reconocida como una artista importante; en este sentido, es necesario resistir el 
impulso de desvirtuar la institución artística sin más, a pesar de sus evidentes contradicciones. La imagen hubiera tenido un efecto diferente si se hubiera presentado, digamos, como un tributo a la campesina caída de parte del periódico. González, reconocida y reverenciada, ocupa una posición privilegiada desde la cual sus acciones y sus peticiones públicas adquieren resonancia. Su firma en la base de la imagen le otorga estatus de obra de arte; la agencia de la obra es amplificada por la agencia de la artista como autora. La institución del arte funciona como un sitio simbólico desde el cual la artista puede hablar y ser escuchada, producir imágenes que serán vistas. El reconocimiento que tiene González como artista y el estatus de la imagen como obra de arte funcionan en conjunto para separar a esta última de las formas y funciones habituales que cumplen las imágenes periodísticas, permitiéndole así a la obra adquirir resonancia social.

Esta obra de González sirve como introducción al tema del rol de los medios masivos en relación con la guerra. Para los sectores de la sociedad colombiana que suelen constituir el público de este tipo de obras de la cultura visual, la experiencia de la guerra es una experiencia mediada. Un flujo constante de imágenes y narrativas, a veces explícitas y brutales, produce una representación de la guerra relativamente estable, la cual sobreenfatiza el terrorismo de las guerrillas en tanto que obscurece la complejidad de los orígenes y las causas del conflicto, así como los crímenes que el Estado mismo ha cometido. Como se sabe, los dos periodos presidenciales de Álvaro Uribe Vélez (2002-2010) se enfocaron en el proyecto de derrotar militarmente a las FARC, apoyándose para tal fin en una estrategia comunicativa agresiva que recurrió a representaciones estereotípicas de los actores del conflicto y a narrativas simplistas. Los medios masivos, los cuales en Colombia han estado históricamente alineados con el establecimiento, han hecho eco de este discurso -y continúan haciéndolo- ad infinitum.

La efectividad de la estrategia de comunicación para producir un respaldo hegemónico alrededor del propósito de derrotar a las guerrillas, así como su efectividad para oscurecer la complejidad de la guerra, ha sido objeto de estudio por parte de investigaciones académicas recientes ${ }^{8}$. Pero yo añadiría a lo que se ha dicho al respecto que las imágenes de la guerra han resultado en una combinación de (shock), apatía y distanciamiento que marca la experiencia de sectores urbanos cuyo conocimiento de la guerra no es directo sino mediado -tal vez algo así como lo que la teórica del afecto Sianne Ngai califica de "estuplime": aquello que produce una combinación de (shock) y apatía (Ngai, 2007, p. 248) ${ }^{9}$. Esta compleja modalidad afectiva es tal vez única a la sociedad colombiana en tanto que su "anacrónico" conflicto de relativamente baja intensidad no tiene paralelos históricos; en cualquier caso, dicha modalidad tiende a restringir el compromiso ético y social. Un sector amplio de la sociedad colombiana experimenta el conflicto armado desde cierta distancia. Seguramente, la distancia y la apatía a través de las cuales la sociedad urbana se relaciona con la guerra, con su producción de sufrimiento y con sus víctimas, es un elemento intrínseco del trauma colectivo de la sociedad colombiana en su totalidad. La cultura visual media esta distancia, tanto como media la distancia geográfica entre las urbes y los escenarios de la guerra.

Desde que Guy Debord publicó su Sociedad del espectáculo, ha sido común argüir que la abundancia de imágenes que plasman actos horribles de violencia tienen el efecto de anestesiar a quienes las miran. No deseo intervenir aquí en el debate que esta posición ha producido. Ciertamente, podemos afirmar en relación con la guerra en Colombia que, como dice Susan Sontag (2004), la función mediadora de las imágenes es idiosincrásica de un sector de la sociedad que se puede permitir el lujo de no tener que afrontar directamente las horribles 
realidades de la guerra, y debería por lo tanto no ser tomada como un hecho universal ${ }^{10}$. Pero esto no debería prevenirnos de ver que la forma de anestesia a la que Ngai califica de "estuplime" ha sido el resultado de la exposición constante a imágenes de la guerra. Freud sostiene que una función de la conciencia es actuar como un escudo que protege al organismo de las "energías excesivas" provenientes del mundo exterior (Freud, 1992) ${ }^{11}$. Siguiendo esta productiva intuición freudiana, podemos decir que la exposición excesiva a imágenes de cadáveres sangrientos y violencia explícita lleva a que nuestro sistema cognitivo les niegue un lugar dentro de nuestra experiencia psíquica consciente ${ }^{12}$. Tal, sostengo, es el efecto para muchos colombianos de la sobreabundancia de imágenes chocantes en años recientes: las imágenes de los cuerpos desfigurados e hinchados de comandantes guerrilleros abatidos o de campesinos sufrientes o en duelo producen un choque paralizador en nuestra psique que, a través de su repetición continua, tiende a traducirse en distanciamiento y apatía, una incapacidad de ser afectado de una forma que pueda conducir a emprender acciones socialmente productivas.

Al sostener esta posición, no quiero implicar que la sobreabundancia de imágenes violentas siempre producirá distancia y apatía, lo que digo es precisamente lo contrario: los efectos producidos por dichas imágenes son relacionales y, por lo tanto, contingentes. Estos efectos deben ser considerados en relación con medios socioculturales y ecologías de imágenes específicas. En nuestra actual ecología de las imágenes, la anestesia que los sujetos urbanos experimentan como consecuencia de la exposición constante a imágenes de violencia difícilmente puede ser combatida a través de un trabajo cultural que recurra a tácticas de (shock) similares a aquellas a las que recurren los medios masivos, como las imágenes explícitas de cadáveres ensangrentados; estas impactan, pero de una forma que se torna contraproducente por el hecho de que no registran en la conciencia de una manera significativa. Al no ensamblarse con nuestros recuerdos y discursos de lo real, el impacto de este tipo de imágenes es meramente sensorial. Insignificantes a pesar de su potencial significativo, tales imágenes son relegadas al ámbito del espectáculo. Así, las consumimos irreflexivamente, un consumo que, como dice Sontag (2004), es frecuentemente lascivo. Una vez que el sentido las abandona, las imágenes de hechos traumáticos y horribles se convierten en objetos de un disfrute descomprometido ${ }^{13}$.

Así, en una movida más o menos consciente, la cultura visual contemporánea en Colombia intenta posicionarse a una distancia adecuada en relación con el sufrimiento y el trauma de la guerra. Podemos ver el distanciamiento producido por nuestra actual ecología de las imágenes en relación con la guerra, las formas en que imágenes de registros disímiles se condicionan entre sí y la forma en que la cultura visual contemporánea busca posicionarse adecuadamente en una película reciente del director Oscar Campo, Yo soy otro (2008, figura 5). Esta película es un thriller psicológico. Cuenta la historia de un ingeniero de programación que lleva una vida hedonista en Cali. Al comienzo de la película, lo vemos ver televisión de manera desafectada: Ios reportes de noticias anuncian que se llevan a cabo combates armados mientras que la pantalla arroja imágenes de soldados disparando, explosiones de artillería, civiles sufrientes y pueblos destruidos. José, el personaje principal, ve estas imágenes sin ser movido por ellas; se levanta en la mañana viéndolas, las mira mientras se lava los dientes, y sigue adelante con las actividades de su día. Pero, un día, José desarrolla ampollas purulentas. En tanto que su enfermedad empeora, empieza a ver versiones de sí mismo en situaciones cada vez más perturbadoras. En tanto que la película avanza, queda claro que los distintos Josés son alegorías de las distintas posiciones ideológicas dentro del conflicto armado: algunas 

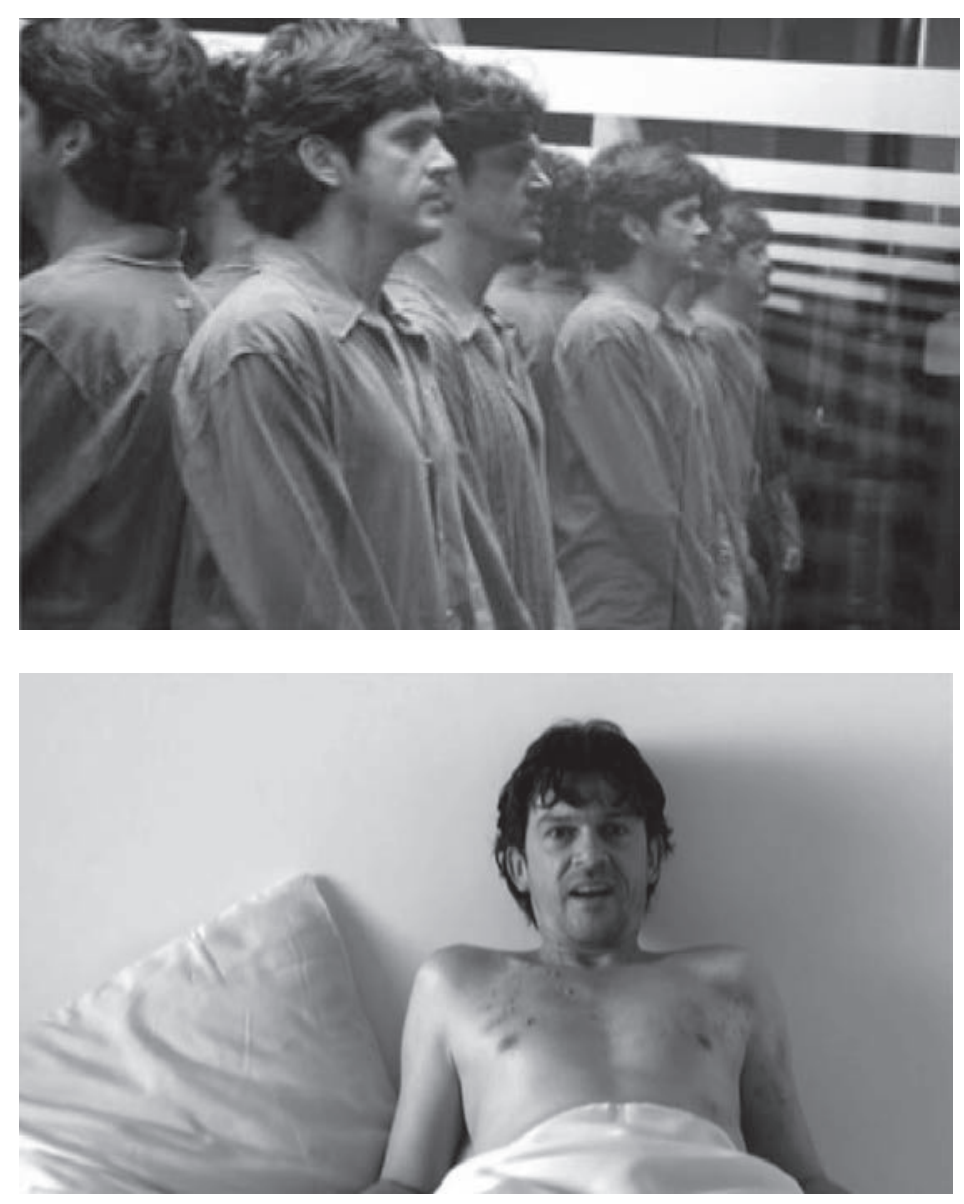

Figura 5. Yo soy otro de Oscar Campo, 2008.

de sus versiones comparten los objetivos e ideales de las guerrillas, mientras que otras se alinean con el establecimiento y con los objetivos de los grupos paramilitares. Su enfermedad, a su vez, funciona como una alegoría del derrumbe de su mundo hedonista.

La actitud de José ante las imágenes violentas emitidas por su televisor ilustra bien el distanciamiento y la apatía a las que me he estado refiriendo. Pero, de manera más importante, la película relaciona secuencias de imágenes de registros diferentes: por un lado, imágenes de ficción que siguen las convenciones del género thriller y, por el otro, imágenes de noticieros e imágenes documentales de la guerra. Estas imágenes, las cuales podemos identificar a través de su distintiva textura visual, son absorbidas por la narrativa de la película, convirtiéndose así en parte del mundo ficcional de esta. Pero, a la vez, las secuencias documentales y de noticiero le otorgan a la narrativa ficcional un registro visual y un valor ético diferente. Ellas configuran lo que la teórica del cine Vivian Sobchack (2004, p. 258) llama la "embestida de lo real": el efecto que resulta de relacionar una narrativa ficticia con el mundo de la vida "real", con un tejido existencial compartido, el resultado del hecho de que identificamos dichas secuencias como fragmentos del mundo que habitamos ${ }^{14}$. A través de esta interrelación de secuencias de imágenes, el contexto "real" de la guerra se convierte en un marco que establece el tono ético con el cual recibimos la narrativa de la película. Las secuencias documentales y la ficción fílmica se han influenciado mutuamente, permitiendo que la película funcione como una alegoría de las contradicciones morales internas albergadas no solo por José sino también por el espectador. 
Pero lo más interesante de esta película en el contexto de este ensayo es que media la guerra a través del género thriller. Yo soy otro es, antes que nada, una película de ficción y no oculta su intención de entretener. En este sentido, se encuentra lejana de las diversas formas de realismo social que han marcado la estética de otras películas políticamente comprometidas, tanto en la historia general del cine como en la local ${ }^{15}$. En esta película, las convenciones del género thriller son puestas al servicio tanto del entretenimiento como de la producción de una relación ética y afectiva con las realidades de la guerra. El personaje principal experimenta una serie de episodios extraños que progresivamente cumplen la promesa del género de provocar emociones (thrills), de sorprender y emocionar; a la vez, los espectadores urbanos podrían encontrarse a sí mismos identificándose con su personaje principal -una identificación que Campo facilita a través de su uso de diversas técnicas cinematográficas de sutura. En este sentido, los dilemas de José se convierten en los del espectador; más allá de esto, el proceso de identificación se ensambla con la conexión con el mundo habitado por el espectador que la película elabora a través de su uso de imágenes de noticiero y documentales. El resultado es que tanto la interpretación de la narrativa como los afectos que la película produce exceden los límites de la mera ficción o del entretenimiento.

Al relacionar la cultura visual con la ecología de las imágenes, no pretendo desvirtuar las distintas historias de las disciplinas -arte, fotografía, cine- a partir de las cuales emergen. Es necesario oponerse a los discursos que, desde el campo de cierta visión reduccionista de los estudios visuales, proclaman la irrelevancia y aun la "muerte" de la historia del arte. Mientras que el enfoque en la vida social de las imágenes sí implica un distanciamiento de la historia del arte entendida como el marco predominante para la interpretación de la cultura visual, no significa que ya no sea necesario pensar según sus términos; más bien, se trata de relativizar su importancia, de verla como una dimensión -importante, por cierto- de la ecología de las imágenes. La vida social de las imágenes y de los objetos de la cultura visual está informada por su relación con las historias de las disciplinas desde las cuales dichas imágenes y objetos emergen: en buena medida, estas últimas elaboran su sentido y significado social en relación con imágenes y objetos del mismo raigambre, aún hoy.

En el contexto colombiano, la cultura visual interviene en debates culturales relacionados con la representación de las víctimas de la guerra, con sus experiencias traumáticas y su sufrimiento. Si a finales de los años sesenta y setenta hubo, especialmente en el cine y la fotografía, un énfasis relativo en la representación "realista" del dolor, el sufrimiento y la miseria que provocó acusaciones de cooptación y etiquetas tales como "pornomiseria", la cultura visual contemporánea recurre a estrategias más conceptuales, alegóricas o poéticas ${ }^{16}$. Así, los procesos de la historia del arte en cierta medida le responden a los afectos contraproducentes producidos por las representaciones hegemónicas de la guerra; ellos median a su manera los problemas de distanciamiento que la cultura visual debe afrontar en relación con su función mediadora.

Entender las obras de la cultura visual como mediaciones del conflicto armado en relación con una ecología de las imágenes es enfatizar la dimensión relacional de los objetos y de las imágenes, y, por lo tanto, su mutabilidad. La modulación de las interrelaciones producidas por la cultura visual implica la dimensión del tiempo: lo que la cultura visual hace, los discursos que pone de relieve y los afectos que produce cambian con el tiempo. La función mediadora de la cultura visual puede verse fortalecida o debilitada por los cambios y modulaciones en la esfera de las imágenes dentro de la cual emergen, y en relación con modulaciones y cambios más generales dentro del medio sociocultural. Esto significa que, entre otras cosas, si se ha de 
mantener, la función mediadora de la cultura visual tiene que ser actualizada continuamente. También significa que las obras de la cultura visual no deben ser concebidas como significantes congelados y contenedores de afecto, sino que deben ser vistas como eventos.

\section{EVENTOS VISUALES}

Las obras que hacen parte de la cultura visual constituyen interrelaciones complejas; ellas hacen su trabajo como mediaciones de la guerra colombiana emergiendo a partir de una esfera de imágenes que produce apatía y distanciamiento. Es decir, las obras de la cultura visual emergen como eventos. Tomando como punto de partida la ontología de la obra de arte de Heidegger (1971), defino a las obras de la cultura visual como eventos en tanto que constituyen una emergencia compleja que produce tanto una espacialidad como una temporalidad, interrelacionando diversos factores: la materialidad de las imágenes, los objetos y las acciones presentadas, los discursos transmitidos por estos elementos, los afectos y las sensaciones que provocan, y los discursos que enmarcan a estos últimos. Estos elementos, a su vez, se ensamblan con los discursos y los marcos que el espectador/participante relaciona con ellos, así como los afectos que los acompañan ${ }^{17}$. En relación con la cultura visual, veo al evento como una erupción, una emergencia que interrelaciona elementos dispares a través de la cual se suspenden las interrelaciones que configuran el mundo habitual; en relación con el conflicto armado colombiano, esta interrelación, como he argüido, está fuertemente informada por la esfera de las imágenes producidas por los medios masivos. El evento es un compuesto, un ensamblaje, en el sentido que Gilles Deleuze y Felix Guattari (1992) le dan a este término: la contigüidad de diversos elementos sin seguir un principio de organización establecido a priori. En este sentido, el evento es inherentemente relacional, espacial y temporal, así como lo son las interpretaciones y las reacciones afectivas que provoca ${ }^{18}$.

Al pensar en la cultura visual en términos del evento, lo que parece fundamental es considerarla como una interrelación compleja apoyada en la preeminencia de lo visual, un ensamblaje de elementos visuales coexistentes, puestos en relación aun cuando siguen modulándose, envolviéndose y transformándose entre sí. Estos elementos, sin embargo, no se encuentran nunca cerrados o completos, ellos son complementados por los marcos que el espectador trae a colación. Podemos decir, en términos deleuzianos, que el evento siempre está deviniendo: como tales, las obras de la cultura visual siempre están desenvolviéndose, buscando alguien que asuma su llamado; conversamente, cada espectador trae a ellas un conjunto único de marcos interpretativos y afectivos. Pero los diferentes elementos y marcos gravitan con distintas fuerzas en la experiencia del espectador; una vez más, se trata de un asunto de grados. Aquí me apoyo en la distinción que hace Henri Bergson (1959) entre la actualidad y la virtualidad del tiempo ${ }^{19}$. Algunos elementos del ensamblaje se sienten más "reales" del momento presente, más actuales, mientras que otros son percibidos como relativamente menos reales, estos es, como virtualidades. En tanto que, como seres humanos, siempre estamos buscando sentido en las cosas, los discursos y las narrativas producidas por la materialidad del evento visual generalmente toman el lugar de lo actual en relación con los afectos y las sensaciones que el evento provoca. De la misma manera, la presencia material del evento visual generalmente ocupa el lugar de lo actual en relación con los discursos y los afectos que el espectador trae al evento, los cuales toman el lugar de lo virtual. 
Discurso, narrativa y significado tienden a tomar prioridad: esta pintura representa los fantasmas de los masacrados; esta película es sobre un grupo de soldados que se encontró una guaca. ¿Pero qué sucede cuando los elementos "fuertes" de la relacionalidad receden? Puede suceder que los elementos "débiles" tomen preeminencia de formas interesantes. Consideremos, por ejemplo, Porfirio, de Alejandro Landes (2012). Esta película se refiere a hechos "reales" que tuvieron al señor Porfirio Ramírez como protagonista. En 1991, Porfirio y su hermano fueron abordados por policías mientras estaban sentados en la sala de la casa de este último, en el municipio de Playa Rica, el cual se encuentra en una de las zonas rojas del conflicto. Los policías los acusaban de ser guerrilleros. En eventos oscuros, Porfirio fue herido de bala en la espalda y quedó parapléjico. Empobrecido y sin poder conseguir una indemnización del Estado, Porfirio decidió secuestrar un avión. Cuando el avión aterrizó en Bogotá, un equipo negociador del gobierno le prometió una indemnización y el perdón de sus acciones. Ambas promesas resultarían falsas.

Pero Porfirio se enfoca muy poco en la narración de la historia de Porfirio; de hecho, se podría decir que en la primera mitad de la película no pasa casi nada. La película no nos ofrece una narrativa progresiva; no hay una diégesis que se desenreda paulatinamente. La primera mitad de la película sucede dentro de la casa de Porfirio: lo vemos en su lucha física por intentar sobrellevar sus actividades cotidianas con la ayuda de su hijo y de su compañera. Esta primera parte resalta la poca agencia física de Porfirio. Su propósito no es contar la historia de Porfirio, sino explorar lo que su cuerpo puede -y no puede- hacer. Solo veremos a Porfirio salir de su casa en la segunda mitad de la película: va a la oficina de su abogado, va a una prendería a empeñar su teléfono, visita al reparador de su silla de ruedas y luego regresa a casa. En la segunda mitad de la película, el espacio diegético se expande y contrae según las acciones de Porfirio. Eventualmente lo veremos adquirir dos granadas de mano y subirse a un avión, el cual desaparece en el cielo. En la siguiente secuencia, vemos una toma panorámica de un relleno sanitario. Después de un lapso de tiempo considerable, dos explosiones interrumpen el silencio.

¿Dónde está la historia de Porfirio? No se hace presente hasta el final de la película. Hasta este momento, todo ha sido no sobre su historia sino sobre la actuación de su cuerpo, sobre los afectos que Porfirio le da a su cuerpo mientras lleva la vida en medio de limitaciones físicas. No hay un "significado" que podamos extrapolar de este performance, sino que, más bien, la narrativa recede para que el afecto tome prioridad. A través de su performance, Porfirio expresa una especie de expectativa desapasionada, de frustración contenida, si bien salpicada con momentos de ternura. La cámara toma distancia, se emplaza de manera neutral, no con el propósito de permitir que la historia se desarrolle ante ella sin su inherencia, sino para capturar el cuerpo actuante como, en palabras de Elena del Rio, "el evento-expresión que hace que el afecto sea una materialidad visible y palpable" (2008, p. $10)^{20}$. La narrativa recula y el cuerpo de Porfirio se convierte en un evento-expresión en vez de un significante que requiere interpretación. Aquí, el afecto toma el lugar de lo virtual. La película interrelaciona el cuerpo de Porfirio en acto, el espacio en el que actúa, las relaciones entre su cuerpo y los de su compañera e hijo con el fin de provocar una reacción afectiva en el espectador.

Sin embargo, la historia de Porfirio no está necesariamente ausente del evento fílmico. Los espectadores colombianos quizás recordarían la historia a partir de las noticias de prensa y la televisión. También podrían no haberse enterado inicialmente -eventos inauditos como los que le ocurrieron a Porfirio no son inusuales en Colombia y por lo tanto es plausible que pasen 


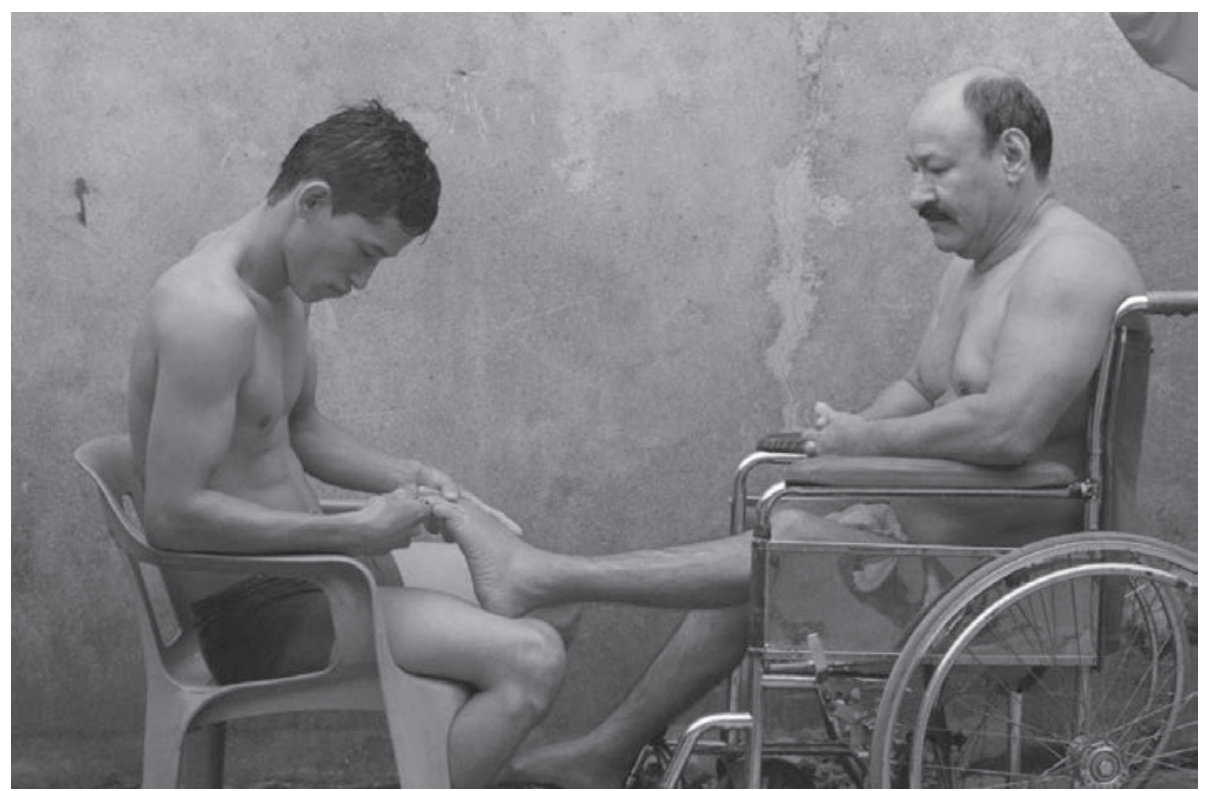

Figura 6. Porfirio, Alejandro Landes, 2012.

sin ser notados- pero la podrían haber conocido eventualmente a través de la lectura de reseñas o críticas de la película. La historia de Porfirio se encuentra presente en el trasfondo, tomando el lugar de lo virtual. Pero esta lógica es reversada al final de la película, cuando vemos a Porfirio sentado contra las paredes blancas del frente de su casa mientras canta su historia a capella. Solo en este momento descubrimos que Porfirio ha sido encarnado por él mismo. De repente, los afectos producidos en Porfirio entran en relación con el mundo del espectador. La narrativa reclama su función de marco, otorgándole valor ético a los afectos producidos por la película en tanto que ella ahora es el testimonio de los eventos que ocurrieron en el mundo que habitamos, el testimonio de una injusticia producida por la guerra que nos ha afectado a través del evento fílmico y frente a la cual sentimos que tenemos responsabilidad.

Lo crucial es el ensamblaje; lo importante es el peso con el que los distintos elementos que intervienen en el evento gravitan en la experiencia del espectador, las formas en que estos elementos se conectan con los discursos y los afectos que el espectador trae a colación, o, más importante, la forma en que estos últimos son transformados. Mientras que en el ejemplo dado aquí la experiencia del espectador está marcada por la tensión entre elementos narrativos/discursivos y elementos afectivos, es importante notar que estos términos no tienen que ser polos opuestos: narrativa y discurso pueden convertirse en productores de afecto en tanto que estos últimos pueden cambiar el sentido o el valor ético de los primeros. Lo actual y lo virtual no se anulan mutuamente, sino que informan el uno al otro con distinta intensidad. Estas dimensiones se ensamblan con densidad variable, y esta densidad puede además modularse y variar al interior del evento visual.

La cultura visual contemporánea funciona como mediación de la guerra colombiana a través de la producción de este tipo de eventos. Lo importante aquí no es lo que el evento presenta, ni los discursos o el sentido que promueve. Como he sugerido, parece haber poco interés en producir representaciones de los eventos de la guerra en la cultura visual de años recientes. Si deseamos aprender sobre la historia del conflicto, debemos buscarla en otro lugar. El carácter efímero de algunas de las obras de la cultura visual contemporánea -como, 
por ejemplo, el performance o algunas instalaciones- desvirtúan cualquier intención de que sirvan para establecer la historia. Más bien, el aspecto central del trabajo de la cultura visual como mediación es la interrelación que construye: las conexiones afectivas que produce, el reemplazo de la apatía y el distanciamiento por afectos más productivos, la producción de contigüidad allí donde solo había distancia.

En relación con la producción de violencia y sufrimiento, de trauma individual y colectivo, de injusticia, de vidas y cuerpos rotos, los eventos producidos por la cultura visual contemporánea buscan deshacer la desafección que parece marcar la experiencia de algunos de los sectores sociales que constituyen su audiencia principal. En este contexto, la producción afectiva de la cultura visual se torna fundamental, ya que el afecto está intrínsecamente relacionado con la acción. Si los colombianos que son suficientemente privilegiados como para solo tener que experimentar el conflicto a distancia han de participar en la construcción de la memoria del conflicto y en la transformación de la sociedad, ellos deben encontrar la motivación afectiva que tal compromiso requiere. Los afectos pueden inmovilizar, pero también pueden solicitar compromiso y acción; la intervención de la cultura visual consiste en cambiar unos por otros. En las formas actuales del cuerpo social, en medio de la actual ecología de las imágenes, la función mediadora de la cultura visual consiste en desacomodar a sus sujetos-espectadores, desestabilizarlos, en términos de Deleuze y Guattari, hacerlos vacilar ${ }^{21}$. Su función es erosionar las imágenes, narrativas y discursos hegemónicos que median el conflicto, remover a sus audiencias urbanas de las contraproducentes modalidades afectivas que marcan su relación habitual (o su falta de relación) con el conflicto, instigándolas a mirar, a indagar, a comprender, a comprometerse políticamente.

La cultura visual contemporánea no construirá la memoria de la guerra. Ella no redimirá a la sociedad colombiana. Mucho menos resolverá las problemáticas sociales que subyacen a la guerra. Sin embargo, produce y producirá eventos capaces de mediar la guerra y sus legados en formas que se apartan de la función mediadora de sus contrapartes visuales producidas por los medios masivos. De manera más importante, es capaz de promover el compromiso afectivo y ético con la necesidad de enfrentar el trauma, la violencia y el sufrimiento de la guerra. Su efecto transformativo ocurre en el sujeto, en el que resiste los afectos contraproducentes y las representaciones reduccionistas de la guerra. La cultura visual es el escudo de Atenea de los colombianos izado frente a la medusa de la guerra. El propósito de este ensayo ha sido sugerir un marco conceptual general a través del cual podemos pensar la labor mediadora de la cultura visual en relación con la guerra y, quizás más importante, continuarla.

\section{NOTAS}

1 FARC es el acrónimo de Fuerzas Armadas Revolucionarias de Colombia.

2 Aunque soy consciente de los matices que a veces diferencian los términos "guerra" y "conflicto armado," y de la tendencia a usar este último en el contexto colombiano, uso ambos términos en este ensayo de manera intercambiable para referirme a la lucha armada de relativamente baja intensidad que ha involucrado a fuerzas estatales, paramilitares y guerrilleras.

3 Aquí sigo la noción del derecho a mirar (the right to look) del teórico de los estudios visuales Nicholas Mirzoeff (2013): el derecho a ver aquello que el poder se empeña en mantener oculto. Influenciado por la noción de la distribución de lo sensible de Jacques Rancière, Mirzoeff sugiere que las configuraciones hegemónicas 
del poder operan a través de la determinación de los procesos sociales y políticos, y de los sujetos que son visibles para la comunidad, y cuáles de estos procesos y subjetividades son invisibilizadas. El derecho a mirar busca desacomodar la visualidad (visuality), esto es, la lógica visual del poder.

4 Claro está, el uso de "representación" para referirse a la producción de semejanza visual es reduccionista, especialmente si se tienen en cuenta las múltiples definiciones del término que han desfilado por la estética. En sus usos más amplios, "representación” se refiere a cualquier cosa que le confiere presencia y voz a otra. Este es el uso que Aristóteles le da al término mimesis, el cual algunos autores han traducido como “representación". En este sentido, el término se refiere a una correspondencia entre el objeto que representa y su referente, que se puede dar de distintas formas, las cuales no tienen que pasar por la semejanza. Sin embargo, Platón usa el término mimesis en un sentido algo más estrecho para referirse a un proceso de reflexión de las apariencias del mundo (aunque debe advertirse que este no es el único sentido que le da al término). Para Platón, la imagen es un espejo. Este uso del término ha influenciado fuertemente a la historia del arte occidental y ha condicionado nuestra comprensión actual de la representación como producción de semejanza visual. Si recurro al término "mediación" en vez de "representación" es en parte (aunque esta no es la razón más importante) para evitar las definiciones habituales del término. Ver Halliwell (1990).

5 Tampoco sostendría que hay una diferencia sustancial entre los estudios visuales y los estudios culturales. El profesor Douglas Crimp, por ejemplo, explica que "la cultura visual es el objeto de estudio de los estudios visuales, los cuales son un área más estrecha de los estudios culturales" ("visual culture is the object of study in visual studies, which is a narrower area of cultural studies") (Crimp, 1999, p. 11). La diferencia entre los dos campos es de grados, estos es, de mayor o menor preponderancia de lo visual en el objeto de estudio.

6 Como dice el profesor John Guillory (2010), es dentro de una teoría de la comunicación que el concepto puede ser aprehendido. En este sentido se debe entender por "mediación" la posibilidad de un proceso comunicativo, no un proceso mecánico de transmisión de un mensaje. Como dice Guillory, la distancia entre los términos del proceso comunicativo es la condición de la mediación, ya que permite que los medios sean finalidades en sí mismos, lo cual posibilita la fijación del deseo sobre ellos (es decir, de afecto). En el sentido más amplio, "mediación" denota la agencia instaurada dentro de un proceso de distanciamiento comunicativo, en el cual un contenido particular es expresado y actualizado.

7 Varios autores y publicaciones se refieren a los efectos traumáticos de la guerra colombiana sobre su población civil. En el extenso reporte estatal ¡Basta ya! Memorias de guerra y dignidad (2013), el grupo de investigadores del Centro Nacional de Memoria Histórica insiste que la guerra ha tenido el efecto menos reconocido de naturalizar la violencia en las relaciones cotidianas, un hecho que se torna evidente especialmente cuando se compara a nuestra sociedad con otras a través de la experiencia, como es mi caso. Sobre los efecto traumáticos de la guerra en Colombia, ver también: Herman (2004), Palacios (2003), Pécault (2003), Lira (2010).

8 El libro de la profesora Claudia Gordillo, Seguridad mediática: la propaganda militarista en la Colombia contemporánea (2014), analiza convincentemente los alineamientos ideológicos entre los medios masivos y el Estado en Colombia.

9 "Stuplimity" en el texto original. Me atrevo a proponer "lo estuplime" como traducción al castellano en vez de la opción "estuplimidad", con la salvedad de que se cambia un sustantivo por un adjetivo.

10 Susan Sontag, en su conocido ensayo Ante el dolor de los demás, escribe que "la afirmación de que la guerra, como todo lo demás que parece real, es médiatique, resulta común", y añade unas líneas más abajo en que las que dice que "la realidad se está convirtiendo en un espectáculo es de un provincianismo pasmoso. Convierte en universales los hábitos visuales de una reducida población instruida que vive en una de las regiones opulentas del mundo, donde las noticias han sido transformadas en entretenimiento" (2004, p. 48).

11 Freud escribe: “Esta partícula de sustancia viva flota en medio de un mundo exterior cargado \{laden\} con las energías más potentes, y sería aniquilada por la acción de los estímulos que parten de él si no estuviera provista de una protección antiestímulo" (1992, p. 27).

12 Aquí sigo a Susan Buck-Morss (1992), quien, en su análisis del famoso ensayo de Walter Benjamin sobre el arte y la reproducibilidad técnica, señala que el autor alemán retoma la comprensión freudiana de la consciencia como escudo protector, la cual fue formulada por el padre del psicoanálisis en relación con la neurosis de guerra, y la aplica a la experiencia de la vida moderna urbana en general. Para Benjamin, la experiencia del sujeto habitante de las urbes modernas está marcada tanto por el (shock) como por la anestesia: el exceso de estímulos puede registrar en la consciencia, pero esta no les asigna significado. En la vida moderna, Benjamin sostiene, hay un exceso de estimulación que provoca un estado de (shock) constante 
en el organismo. Más allá de esto, sostiene que el sistema cognitivo responde al exceso de estímulos no impidiendo su registro consciente, sino obstaculizando el ensamblaje de dichos estímulos con los recuerdos de experiencias pasadas.

13 Julia Kristeva (2006) nos dice que lo abyecto produce no solo repulsión, sino también una forma de disfrute que ella llama jouissance. Este disfrute deriva del dolor psíquico producido al entrar en contacto con lo abyecto. Por lo tanto, lo abyecto trabaja en contra del ego, el cual inherentemente busca placer. Mientras que a veces Kristeva sugiere que sentir jouissance puede ser positivo en tanto que resiste los excesos del ego, en el contexto de mi ensayo, toma un cariz negativo en tanto que se opone al placer que el ego deriva del hecho de seguir normas éticas. Jouissance erosiona las conexiones entre las imagines del conflicto y el mundo en el cual el espectador se asume como sujeto de responsabilidades éticas.

14 "The charge of the real" en la version original en ingles. "La embestida de lo real" es una traducción propia.

15 Este es especialmente el caso con algunas de las formas más militantes del cine político que emergieron en el país a partir de la década de los sesenta, las cuales frecuentemente recurrieron a representaciones de violencia cruda y del sufrimiento que ha afectado a las víctimas del conflicto y a los desposeídos en general -y que, en sus versiones más desafortunadas, provocó acusaciones de cooptación y etiquetas críticas tales como el término "pornomiseria". Ver Pulecio (1999).

16 Por favor remitirse a la nota anterior.

17 En El origen de la obra de arte, Heidegger afirma que la obra de arte no es un hecho ya dado, sino una apertura de un mundo que nunca se acaba de producir: esto es lo que está implicado en el uso del participio en el término Ge-stell (com-posición), la forma en que "se presenta la obra en la medida en que se erige y se trae aquí a sí misma" (1971, p. 64). El presentarse y erigirse de la obra es una forma de desplazamiento, donde "seguir estos desplazamientos significa transformar las relaciones habituales con el mundo y la tierra y a partir de ese momento contener el hacer y apreciar el conocer y contemplar corrientes a fin de demorarnos en la verdad que acontece en la obra" (p. 64). Heidegger llama este modo de detenerse en la obra el "cuidado" de la obra: "Cuidar la obra significa mantenerse en el interior de la apertura de lo ente acaecida en la obra" (p. 65). La obra de arte necesita quién la cuide, solicita y se mantiene unida a quienes la cuidan; esta es la precariedad de la obra, su temporalidad, su naturaleza transitoria: la obra de arte solo puede ser en tanto es habitada. En mi concepto de evento visual, suspendo la ontología de la obra de arte como Ge-stell, y coloco el énfasis en la relacionalidad que la obra produce.

18 Ver especialmente Deleuze y Guattari, "Rizoma" (1992).

19 Ver especialmente el capítulo 1 de Materia y memoria: “De la selección de imágenes para la presentación consciente; lo que significa y hace el cuerpo".

20 "The expression-event that makes affect a visible and palpable materiality."Traducción propia.

21 Deleuze and Guattari escriben que "el afecto no es un sentimiento personal, tampoco es un carácter, es la efectuación de una potencia de manada, que desencadena y hace vacilar el yo" (1992, p. 246).

\section{REFERENCIAS}

Bergson, Henri. "Materia y memoria". En Obras completas, trad. José Antonio Miguez. México: Aguilar, 1959.

Buck-Morss, Susan. "Aesthetics and Anaesthetics: Walter Benjamin's Artwork Essay Reconsidered". October, vol. 62 (1992): 3-41.

Crimp, Douglas. "Getting the Warhol We Deserve: Cultural Studies and Queer Culture". En [In] Visible Culture: An Electronic Journal for Visual Studies, 1999. http://www.rochester.edu/ in_visible_culture/issue1/crimp/crimp.html (Acceso: 20 de junio de 2013).

del Rio, Elena. Deleuze and the Cinemas of Performance. Edinburgh: Edinburgh University Press, 2008.

Deleuze, Gilles y Guattari, Felix. Mil Mesetas. Valencia: Pre-textos, 1992.

Freud, Sigmund. Obras Completas, vol. 18: Más allá del principio de placer, psicología de las masas y análisis del yo y otras obras. Buenos Aires: Amorrortu, 1992 [1976]. 
Gordillo, Claudia. Seguridad mediática: la propaganda militarista en la Colombia contemporánea. Bogotá: Corporación Universitaria Minuto de Dios, 2014.

Grupo de Memoria Histórica. ¡Basta ya! Colombia, memorias de guerra y dignidad. Bogotá: Centro Nacional de Memoria Histórica, 2013.

Guillory, John. "Genesis of the Media Concept". Critical Inquiry, vol. 36 (2010): 321-362.

Halliwell, Stephen. "Aristotelian Mimesis Reevaluated". Journal of the History of Philosophy, vol. 28 (1990): 487-510.

Heidegger, Martin. Poetry, Language and Thought. New York: Harper and Row, 1971.

Herman, Judith. Trauma y recuperación. Cómo superar las consecuencias de la Violencia. Madrid: Espasa, 2004.

Kristeva, Julia. Poderes de la perversión. Ensayo sobre Louis-Ferdinand Céline. Madrid: Siglo XXI, 2006.

Lira, Elizabeth. "Trauma, duelo, reparación y memoria". Revista de Estudios Sociales, Bogotá, vol. 36 (2010): 14-28.

Mirzoeff, Nicholas. The Visual Culture Reader. New York: Routledge, 2013.

Mitchell, William J. Thomas. "There are no visual media." En The Visual Culture Reader, $3^{a}$ ed. New York: Routledge, 2013. 7-14.

Mitchell, William J. Thomas. "What Do Pictures "Really" Want?". October, vol. 77 (1996), 71-82.

Ngai, Sianne. Ugly Feelings. Boston: Harvard Univesrity Press, 2007.

Nietzsche, Friedrich Wilhelm. Obra selecta, ed. Germán Cano. Cartoné, Madrid: Editorial Gredos, 2009.

Palacios, Marco. Entre la legitimidad y la violencia. Colombia, 1875-1994. Bogotá: Norma, 2003.

Pécault, Daniel. Violencia y política en Colombia. Elementos de reflexión. Medellín: Hombre Nuevo, 2003.

Porfirio. Dir. Alejandro Landes. Franja Nomo, 2012. Filme.

Pulecio, Enrique. "Cine y violencia en Colombia". En Arte y violencia en Colombia desde 1948, Exhibition catalogue. Bogotá: Museum of Modern Art, 1999. 152-183.

Rancière, Jacques. The Future of the Image. London: Verso, 2009.

Sobchack, Vivian. Carnal Thoughts: Embodiment and Moving Image Culture. Berkeley: University of California Press, 2004.

Sontag, Susan. Ante el dolor de los demás. Madrid: Suma de Letras, 2004.

Yo soy otro. Dir. Oscar Campo. Enic Producciones, EFE-X Cine, Jaguar Films, 2008. Filme.

\section{Cómo citar este artículo:}

Yepes Muñoz, Rubén Darío. "El escudo de Atenea: cultura visual y guerra en Colombia". Cuadernos de Música, Artes Visuales y Artes Escénicas, 9 (2), 23-43, 2014. http://dx.doi. org/10.11144/Javeriana.mavae9-2.eacv 
